\title{
Information and Communication Technology in Higher Education of Uganda and Education Implications: A Case of Kyambogo University
}

\author{
Grace Lubaale \\ Correspondence: Grace Lubaale, Department of Teacher Education and Development Studies, Faculty of Education, \\ Kyambogo University, Kampala Uganda.
}

Received: Mar. 10, $2020 \quad$ Accepted: Apr. 25, $2020 \quad$ Online Published: May 5, 2020

doi:10.11114/jets. v8i6.4842

URL: https://doi.org/10.11114/jets.v8i6.4842

\begin{abstract}
The emergence of knowledge society globally today has created new challenges for Higher Education (HE) particularly with the development of Information Communication Technology (ICT) at a speed that has no match in history yet HE in Uganda is still lagging behind. The paper aims at unraveling the role and challenges of using ICT in HE of Uganda and education implications in order to provide the way forward with Kyambogo University as a case. This paper used a mixed methods approach that combined desk review and interviews. The paper reveals the role of ICT in HE as central in the teaching-learning process, on the learner and learning and on the academic staff and teaching while the challenges as; learners, economy, equipment and academic staff which poses as a drawback in the teaching -learning process. The paper concludes that ICT is central in the teaching-learning process as well as in the management of HE institutions. The way forward rests majorly in the newly created ICT Ministry with effective implementation of ICT Policy 2014 to improve the livelihoods of Ugandans by ensuring the availability of accessible, efficient, reliable and affordable ICT services in which HE will benefit automatically hence its effective application and use in the teaching-learning process.
\end{abstract}

Keywords: role of ICT, challenges of application, higher education, education implications, way forward, Kyambogo University, Uganda

\section{Introduction}

The Information Age (also known as the Computer Age, Digital Age, or New Media Age) is a period in human history characterized by the shift from traditional industry that the industrial revolution brought through industrialization, to an economy based on information computerization through the use and application of ICT gadgets like computers and mobile phones as well as services like internet, social media, e-learning, e-commerce, e-agriculture and telemedicine. Globally, Western and Asian countries in general have embraced ICT in the entire economy including the education system through e-learning, teaching, admissions, registration, examination, assessment, grading, release of results, transcripts \& certificates and management of institutions as well as community service with a ratio of one computer to 15 students (1:15) (Kiptalam \& Rodrigues, 2010). Under the Comprehensive National Development Planning Framework (CNDPF) 2007 and in conformity with the Uganda Vision 2040, Information and Communications Technology (ICT) was identified as one of the key priority thematic areas in the development process hence establishment of the Ministry of Information and Communications Technology (MoICT) in 2011. This further led to the development of the Uganda Communications Act 2013, and the launch of the Information and Communications Technology Sector Strategic and Investment Plan (ICTSIP) which set the National ICT priorities for a 5-year period covering 2015/16 to 2019/20. The plan is expected to improve service delivery, creating employment and wealth to fast track social- economic transformation through utilization of quality as well as affordable ICT services in all spheres of life including education. From such a digit economy, Higher Education (HE) is supposed to benefit and translate that into the teaching-learning process as well as in the management through the use and application of ICT so that all deserving students can access HE and complete on time with easy.

However, HE in Uganda is yet to reach the desired international standards in all learning institutions. Uganda like other African countries still experience a lag in ICT implementation that continue to widen the digital and knowledge divide. In the study by Kiptalam and Rodrigues (2010) observed that access to ICT facilities is a major challenge facing most African countries, with a ratio of one computer to 150 students (1:150) against the ratio of 1:15 students in the developed countries. Further, the report by the National Council for Science and Technology (2010) indicated that computer use in Ugandan classrooms is still in its early phases, and concluded that the perceptions and experiences of teachers and 
administrators do play an important role in the use of computers. There are 48 universities in Uganda that are offering HE, nine are public and 39 are private (NCHE, 2019), all grappling with the ICT inadequacies in their management, teaching-learning process, processing and dissemination of results on time as well as distribution of transcripts and certificates though at different levels. Kyambogo University is one of the universities in Uganda grappling with ICT inadequacies hence its choice as a case.

This paper therefore unravels the role and challenges of using ICT in HE of Uganda and education implications in order to provide the way forward for $\mathrm{HE}$ in $\mathrm{KyU}$ and Uganda as a whole. The paper is organized into six sections namely the introduction, literature review and methodology of the study. The status of ICT at KyU, role of ICT in HE, and the challenges of ICT application and use in HE is extensively discussed in view of the data collected from the respondents. The paper provides a conclusion and recommendations for successful ICT application in HE institutions of Uganda as well as references

\section{Literature Review}

\subsection{ICT Status and Policy in Uganda}

Uganda Communications Act (2013), came into force in 2013 with the objective of developing a modern communications sector, which includes Telecommunications, Broadcasting, Radio Communications, Postal Communications, Data Communication and Infrastructure through the following ways as action/strategic ways of enhancing ICT in Uganda namely: Establishing one regulatory body for communications in accordance with international best practices; Enhancing national coverage of communications services; Expanding the existing variety of communications services available in Uganda to include modern and innovative communications services; Reducing the direct role of Government as an operator in the communications sector and minimizing the subsidies paid by the Government to the communications sector by encouraging the participation of the private sector in the development of the communications sector and establishing and administering a fund for the development of rural communications and ICT in the country. The Communications Act 2013 indeed is central in this paper establishing the role of ICT in HE, and challenges of application because they are bent on its success and will be useful in determining the way forward for HE in Uganda.

The National ICT Policy (2014), came into force in 2014 with the aim of supporting the realization of the Uganda Vision 2040. The broad policy objectives of the national ICT policy are to: Build a knowledge based human capital; Promote innovation in economic and social systems; Expand ICT infrastructure and its integration throughout the country; Deepen utilization of ICT services by government, private sector, Non-Government Organizations and Citizenry; Enhance research and innovation in ICT products, applications, and services; and Improve ICT governance and environment in Uganda. This is expected to propel the country to middle income in 2040 as per Uganda Vision 2040.

The Ministry of Information Communication Technology (MoICT) in the FY2014/15, registered several achievements in the sector namely; The National Backbone Infrastructure (NBI) extended to connect 45 sites with Kampala and Entebbe where 25 universities are found. This enables access of high-speed internet at affordable costs through bulk procurement and Six (6) Public Universities have been connected to the NBI to enable access to high speed internet connectivity and facilitate e-learning and research among others. These are: Gulu University (GU), Mbarara University of Science and Technology (MUST), Kyambogo University (KyU), Busitema University (BU), Makerere University Business School (MUBS), and Uganda Management Institute (UMI). This achievement continues to bear an indelible mark on the ICT status in Uganda and subsequently in HE the focus of the paper.

The Ministry of Information Communication Technology (MoICT), ICT Sector Strategic and Investment Plan (2015/16 $-2019 / 20$ ) is of great value in this paper by giving its achievement in the sector. The Information and Communications Technology Sector Strategic and Investment Plan (ICT-SIP) has been an asset in the strategic positioning of the ICT Sector, promoting ICT as an industry and ensuring the use of ICT as a tool for transforming Uganda into a knowledge-based economy. The Plan has consolidated the achievements so far and addresses the challenges as well as bottlenecks that have been identified over the years. The ICT-SIP has consolidated the achievements attained in the National Development Plan (NDP I) and operationalized ICT priority interventions for NDP II. Attempts have been made to identify and enhance the fundamentals that have supported the ICT Sector over the years, with a view to further consolidating them; identify other priority interventions for ensuring a more conducive ecosystem as well as an institutional arrangement that is appropriate to deliver the goals of the ICT-SIP. This is evident in the table 1 below indicating ICT at glance in Uganda by 2018 . 
Table 1. Showing Uganda's Communications Sector at a Glance By 2018

\begin{tabular}{l|l|l}
\hline S/N & ICT Service & Output \\
\hline 01. & Mobile Subscriptions & $24,388,744$ Million People \\
\hline 02. & Fixed Lines subscription & 186,724 \\
\hline 03. & Tele density (\%) & 63 \\
\hline 04. & Internet subscription (Mobile) & $14,360,847$ Million People \\
\hline 05. & & \\
\hline 06. & Internet subscription (Fixed) & 9,485 \\
\hline 07. & Estimated Internet users & 37 \\
\hline 08. & PSP Voice and Data Licenses & $21,636,121$ Million People \\
\hline 09. & PIP Licenses & 33 \\
\hline 10. & No of operational TV stations & 22 \\
\hline 11. & No of Pay TV service providers & 40 \\
\hline 12. & Active Pay TV Subscriptions & 8 \\
\hline 13. & No of FTA vendors & $2,188,233$ Million People \\
\hline 14. & No of postal and Courier service providers & 19 \\
\hline
\end{tabular}

NB. Population Estimated at: 39,041,200 (UBOS) by 2018

Source: Uganda Communications Communication Sector Performance, December 2018.

\subsection{Role of ICT in Higher Education}

Kayiwa, Raihan \& Che Kum (2014) underscore the vital role of ICT in supporting efficient management and administration in the education sector. They indicate that ICT can be useful in students admission, and administration; process voluminous records quickly, meticulously and impeccably; generate reliable and consistent records which can easily be searchable and quickly retrieved; Digital records save space which is a premium cost to institutions; Saves human resources for data entry and servicing student admission and registration. ICT is indeed useful to expand the geographical boundary of university to offer services to many people; very useful in planning, budgeting, teaching, learning, monitoring and evaluation of all education activities hence central to this paper.

Anwar \& Mathew (2014) empathizes that ICT enhances learning, teaching, comprehension, result processing, and efficiency on the academic staff which are essential in this paper.

Lubaale (2015a) endeavors greatly to show the benefits of ICT in education as enhancing the teaching -learning process, learning, comprehension, and teacher's efficiency which are central in this paper on the role of ICT in HE.

\subsection{Challenges of ICT Application in Higher Education}

The growth of ICT in Uganda is faced with challenges of inadequate infrastructure, insufficient human resource capital and capacity, insufficient funding and weak partnerships, limited public awareness and knowledge, low adoption levels of e-Services, limited investment in research and development, untapped local content, and a weak institutional framework according to the Ministry of Information Communication Technology (MoICT), ICT Sector Strategic and Investment Plan (2015/16 - 2019/20). These challenges of the country indeed have direct bearing on ICT application in HE, the core of this paper.

Nelly (2015) reveals the challenges as limited ICT equipment/ accessories and competence of staff and learners in application besides attitude indeed standout as a drawback in the application of ICT in the teaching and learning in schools in Kenya which is not any different from institutions of higher education in Uganda hence being useful to this paper. 


\subsection{ICT in Kyambogo University}

Kyambogo University (KyU), established in 2003 is one of the nine Public Universities in Uganda and struggling to enhance her ICT which is central in the modern higher education delivery. The challenges of KyU have been inadequate infrastructure of ICT, Staff and Students limited ICT knowledge and application as well as limited funds for investment in ICT hence the continued backward teaching using the chalkboard, delayed processing of results, transcripts and certificates as well as difficulties in fees collections and management communications with students, staff and beyond. Nonetheless, the university is steadily expanding its ICT resources and services. This has been supported by the university's in-house developed software referred to as the e-Kampus System that streamlines fees payment, admissions and registration of students, and dissemination of results to students among others. However, these activities have been reactive responses to challenges the university faced over time rather than pro-active responses guided by policy hence formation of the Kyambogo University Information and Communication Technology Policy, 2014. This policy framework is aimed at providing guidelines to streamline strategic plan to improve the ICT infrastructure and to provide effective management and optimum utilization of ICT resources so that ICT becomes as an integral part of its management and administrative functions using the central storage of data for all staff, students and other business functions. Therefore, ICT policy is a necessity in addressing administration, education, research, innovation and cyber security issues to ensure availability and proper use and utilization of ICT services in the University.

\section{Methodology}

This study used a mixed methods approach that combined desk review and interviews (Creswell, 2017, 2009). Quantitative data was derived from documents while qualitative data was from the interviews. The population of students is 27,325 on campus (Kyambogo University, 2019). A sample of 87 was taken which helped to reach data saturation (Mugenda \& Mugenda, 1999). Stratified simple random sampling was chosen taking care of gender and programme of study (level and nature). Validity of the instruments was ensured by giving to 10 experts in education to judge their appropriateness. From this rating, the Content Validity Index (CVI) was calculated and approved. The CVI for each item was calculated and all items whose score was below 0.8 were modified (Amin, 2005). Reliability of the items was determined using test-retest method. The Cronbach Alpha test score of 0.6 was got for the instrument (Amin, 2005). Data Analysis involved use of Descriptive statistics to analyze the quantitative data while Content analysis was for the qualitative data by identifying themes, summarize the findings (Pope, Mays \& Popay, 2007) and thereafter researchers' interpretation. Ethical Considerations were ensured through confidentiality of participants, ethical approval and use of informed consent (Bean, 2005).

Table 2. Showing Key Characteristics of Respondents

\begin{tabular}{l|l|l|l|l}
\hline S/N & Characteristics & Nature & Number & Percentage \\
\hline 01. & \multirow{2}{*}{ Sex } & Male & 44 & 49 \\
\cline { 3 - 5 } & & Female & 43 & 51 \\
\hline 02. & \multirow{2}{*}{ Level } & Undergraduate & 65 & 75 \\
\cline { 3 - 5 } & & Postgraduate & 22 & 25 \\
\hline 03. & \multirow{2}{*}{ Discipline } & Science & 41 & 47 \\
\cline { 3 - 5 } & & Non-Science & 46 & 53 \\
\hline 04. & Interview & Interview Guide on Themes & 08 & 100 \\
\hline 05. & Method & & & 100 \\
\hline
\end{tabular}

\section{Source: Primary Data, 2020.}

Table 2 above shows the characteristics of respondents as 43 (49\%) female and 44(51\%) male. Undergraduate respondents were 65(75\%) while postgraduates were 22(25\%). Respondents doing Science programmes were $41(47 \%)$ while NonScience were 46(53\%). All respondents were interviewed on all the items in the interview guide and responded to all items thus $100 \%$ response

\section{Results and Discussions}

This section deals with the data as received from the documents and interviews in regard to ICT, interpretation, analysis and discussion. 


\subsection{The Status of ICT in Kyambogo University}

From the documents at KyU, the researcher was able to establish the ICT status at KyU as below by 2019 .

Table 3. Shows the Status of ICT in Kyambogo University by 2019

\begin{tabular}{l|l|l|l|l}
\hline S/N & ICT Item & ICT Target & ICT Actual & \% of Actual ICT \\
\hline 01. & Laboratories & 25 & 17 & 68 \\
\hline 02. & Functional Computers & 1,800 & 862 & 47.8 \\
\hline 03. & Computers with a printer & 1,800 & 00 & 00 \\
\hline 04. & Computers connected to the internet & 1,800 & 562 & 31 \\
\hline 05. & $\begin{array}{l}\text { Academic Institutions Management } \\
\text { Information System (AIMS) }\end{array}$ & & & \\
\hline & - Results Management & 27,325 & 27,325 & 100 \\
\hline & -Admissions & 27,325 & 27,325 & 100 \\
\hline & -Registration of learners & 27,325 & 27,325 & 100 \\
\hline & - Personal files of Learners & 27,325 & 27,325 & 100 \\
\hline & -Finance (Payments) & 27,325 & 27,325 & 100 \\
\hline & -Programmes and Courses & 155 & 80 & 45 \\
\hline & - Students Photos Management & 27,325 & 27,325 & 100 \\
\hline & -Transcripts and Certificates & 27,325 & - & - \\
\hline 06. & Mobile phones' Ups Function & 27,325 & 13,663 & 50 \\
\hline 07. & Campus Net Work & 27,325 & 13,663 & 50 \\
\hline
\end{tabular}

Source: ICT Directorate of Kyambogo University Records, 2019.

From the table 3 above, the researcher was able to establish that there are 17 ICT laboratories still below the target of 25 . The functional computers are 862 far below $50 \%$ of the target. Computers with printer for students to print was none and those connected to the internet all the time were $31 \%$ below even the average. The Academic Institutions Management Information System (AIMS) which is a national programme in Public Universities of Uganda was found to be active in $\mathrm{KyU}$ in terms of Results Management, Admissions, Registration of learners, Personal files of Learners, Finance (Payments), Programmes and Courses Students, Photos Management, and Transcripts and Certificates although with difficulties ranging from limited facilities, staff and students ICT competence inadequacies and irregular electricity. Mobile phones Ups Functions and Campus Network continue to function at 50\% largely because students do not have personal smart phones and laptops to access these services all the time. Besides some lacking skills to operate them.

\subsection{The Role of ICT In Higher Education and Education Implications}

From the interviews, the respondents were asked the role of ICT in HE and they responses are categorized into four themes namely: Learners and Learning, Teaching-Learning Process, Academic Staff and Teaching and Management of Higher Education Institutions.

Table 4. Shows A Summary of The Themes, Respondents and Responses on The Role of ICT In Higher Education and Education Implications

\begin{tabular}{|c|c|c|c|c|c|}
\hline $\mathbf{S} / \mathbf{N}$ & Theme & Sub Theme & $\begin{array}{l}\text { Number of } \\
\text { Respondents }\end{array}$ & $\begin{array}{l}\text { Response } \\
\text { Status }\end{array}$ & Summary of Response \\
\hline \multirow[t]{4}{*}{1.} & \multirow{4}{*}{$\begin{array}{l}\text { Learners and } \\
\text { Learning }\end{array}$} & General use of ICT & 87 & Positive & ICT Enhances Learning in HE \\
\hline & & $\begin{array}{l}\text { In regard to } \\
\text { Motivation and Skills }\end{array}$ & 87 & Positive & ICT Enhances Learning in HE \\
\hline & & $\begin{array}{lcr}\text { In regard to } & \text { to } \\
\text { Independent learning }\end{array}$ & 87 & Positive & ICT Enhances Learning in HE \\
\hline & & $\begin{array}{l}\text { In regard to } \\
\text { Teamwork }\end{array}$ & 87 & Positive & ICT Enhances Learning in HE \\
\hline 2. & \multicolumn{2}{|c|}{ Teaching-Learning Process } & 87 & Positive & ICT Enhances teaching in $\mathrm{HE}$ \\
\hline 3. & \multicolumn{2}{|c|}{ Academic Staff and Teaching } & 87 & Positive & $\begin{array}{l}\text { ICT Enhances Academic Staff } \\
\text { Performance in HE }\end{array}$ \\
\hline 4. & \multicolumn{2}{|c|}{$\begin{array}{l}\begin{array}{l}\text { Management of Higher } \\
\text { Institutions. }\end{array} \\
\end{array}$} & 87 & Positive & $\begin{array}{l}\text { ICT Enhances efficient and } \\
\text { effective Management in HE }\end{array}$ \\
\hline
\end{tabular}

Source: Primary Data, 2020. 
Table 4 above shows that all the respondents responded on themes positively and below is the detailed response and interpretation.

\subsubsection{Learners and Learning}

This dealt with the learners themselves and the outcome of learning as a result of ICT in the university. From the responses, it is clear that there is a considerable positive role with great impact on the learners and learning as illustrated below:

General Use of ICT: ICT provides structured approaches to Internet research that enhances development of students' search and research skills which are transferable across the curriculum, said an undergraduate non-science female respondent.

ICT impacts positively on educational performance of learners and the gap is always seen between learners who use ICT more often than others in all disciplines, said a science postgraduate female respondent.

Use of ICT improves attainment levels of learners in English language the medium of instruction in Uganda, and enhances their comprehension of other disciplines in HE, said a male science undergraduate respondent

A male postgraduate non-science student asserted that Institutions with higher levels of e-maturity demonstrate a more rapid increase in performance scores than those with lower levels. Furthermore, institutions with good ICT resources achieve better results than those that are poorly equipped.

Learner's subject-related performance and basic skills (calculation, reading and writing) improve with ICT, a female science undergraduate student said.

Academically strong students benefit more from ICT use and continue to excel because of ICT applications. However, on a positive note, even time takers gradually improve with time in performance once they continue to use ICT. This is evident in the better performance of more and more students as better because of ICT than before ICT era, a female non-science undergraduate respondent asserted.

From the above responses, it is clear that ICT enhances performance in HE in terms of knowledge acquisition, comprehension, and research hence better overall performance. A case in point, in the beginning of KyU with about 13000 students in 2003, with less ICT infrastructure, the first-class graduates were less than 100 but with heavy investment in ICT and application by students, there are 187 first class degrees and 388 distinctions for diplomas by 2019 (KyU Graduation Booklet, 2019). This improved performance is attributed partly to ICT as many academic staff, scholars and students are becoming more and more convinced that the educational achievements of learners improve with the use of ICT.

In regard to Motivation and Skills: ICT has a strong motivational and positive effects on behaviour, communication and processing skills, said a male science undergraduate student.

Use of ICT; Projectors, White Boards, Power PowerPoint, and TV Screen shows are highly engaging and motivating, particularly for grown up learners in tertiary institutions and indeed pay more attention during lessons, said a female non-science postgraduate student.

From the above responses, it is clear that ICT enhances motivation and skills which increase learning and eventual better performance. This is buttressed with evidence in Europe where a very high $86 \%$ of teachers state that pupils are more motivated and attentive when computers and internet are used in class (Empirica, 2006; Passey \& Rogers, 2004). Therefore, it is increasingly becoming clear that there is much of a pedagogical advantage of computer use in class than in its absence.

In regard to Independent learning: Learners state that they do assignments more on their own way when using a computer, said a male non-science undergraduate respondent.

Academic staff consider learners work more organized and comprehensive with use of ICT hence a big impact on both academically strong and weak students, said a female science postgraduate respondent.

ICT use at Universities greatly helps to minimize the social divide by reducing the digital divide which is a challenge in a developing country like Uganda, said male science undergraduate respondent.

Students become more responsible for their own learning while using ICT, and work more independently and effectively than when the academic staff lecture so much in the name of giving the subject content matter in the absence of ICT, said a male non-science undergraduate respondent.

ICT offers learners assignments better suited to individual needs and makes it easier to organize their own learning like use of digital portfolios, said a female non-science undergraduate respondent. 
From the above responses, it is clear that ICT enhances independent learning which is central in academic excellence. As noted above, once learners are motivated, and have the ICT equipment, they can competently work on their own which culminates into greater academic excellence.

In regard to Teamwork: Collaboration among students is greater when they use ICT for project work, and course work as well as academic staff and students. (A female non-science undergraduate respondent said).

Peer to peer support in learning in order to excel is greater with ICT. (A male science undergraduate respondent said).

Independent research and support of one another in putting their work together for common understanding before submission is greatly enhanced by ICT. (A female non-science postgraduate respondent said).

From the above responses, team work among learners is enhanced because of ICT which enhances performance in Higher Education Institutions.

\subsubsection{Teaching-Learning Process}

This dealt with the teaching-learning process which is central in the overall performance of learners once done well. Therefore, the issue here is the contribution of ICT to this process and the eventual outcome. From the responses, it is clear that there is a considerable positive role of ICT in the teaching-learning outcome as evident below:

Proper use of ICT gargets like projectors, cameras, and TV screens increase learning because of easy visibility of pictures, maps, and animals among others. (A female non-science undergraduate respondent said).

ICT as a medium for teaching and learning is a great tool through which academic staff can teach and learners can learn better through use of teaching methods like discussion, lecture, think-pair and discovery hence enhancing better comprehension. (A male science undergraduate respondent said).

ICT as a device indeed greatly helps in the giving, writing, and marking assignments or written examinations as well as compiling results, collecting data, storage, processing, conducting research and dissemination of outcomes. (A male science postgraduate respondent said).

In view of the above, proper use of ICT enhances comprehension of the subject matter as well as discipline in the class as a result of a good teaching-learning environment equipped with ICT

\subsubsection{Academic Staff and Teaching}

This was on the academic staff himself or herself while preparing before teaching, during teaching and after teaching with a view of good performance from the side of the students. Respondents were in agreement that ICT enables academic staff to teach well as evident below:

ICT gargets like Projectors, White Boards, and TV Screens increase classroom interaction between academic staff and learner's interaction which makes the academic staff an advisor and facilitator than a dictator and all-knowing as used to be. (A female science undergraduate respondent said).

ICT enables academic staff to engage students more actively in the creation of knowledge and dissemination. Proper use of ICT by the Academic staff for communication in the teaching and with learners from time to time creates a favorable learning environment that makes learners active in the knowledge production than just being passive consumers. (A male non-science postgraduate respondent said).

ICT creates enthusiasm and positive attitude towards teaching by the academic staff in terms of preparation, teaching and research which is enhancing better academic performance of learners as result of good preparation from academic staff. (A female science undergraduate respondent said).

Efficiency and effectiveness in lesson delivery are evident in the academic staff use of ICT through proper planning, preparation, and collaboration. (A male non-science undergraduate respondent said).

It increases academic collaborative approach among themselves. ICT enables academic staff to cooperate more and share curriculum plans with colleagues and University managers. (A male science postgraduate respondent said).

From the above responses, clarity is adduced that ICT has an indelible mark on the academic staffs' performance and teaching output in terms of preparation, delivery, conferencing, and producing results. It is even evident with issuing 
teachers with their own laptop computer in some European countries increased their attitudes towards work (Becta, 2003 \& Scrimshaw, 2004).

\subsubsection{Management of Higher Education Institutions}

This dealt more with the management function in which students are the greatest beneficiary like The Academic Institutions Management Information System (AIMS) which is a national programme in Public Universities of Uganda where KyU is active in terms of Results Management, Admissions, Registration of learners, Personal files of Learners, Finance (Payments), Programmes and Courses Students, Photos Management, and Transcripts and Certificates. From the respondents, there is considerable evidence of the role/impact of ICT in the management of HE institutions as evident below in the testimonies of respondents of $\mathrm{KyU}$ :

Advertisings of HE institutions is greatly done by ICT gargets like Tele Vision, Radios, Print media, Tele phones, Internet as well as Websites posting and search. From these platforms, potential learners get to know the various programmes offered in these institutions and apply. (A female science undergraduate respondent said)

Admissions are now done online in some institutions in Uganda like Kyambogo University where potential learners after viewing the advertisement in the media, they apply for the various programmes of choice and interest. Selections are done using ICT and feedback given to the applicants online. (A male science undergraduate respondent said).

Day to day correspondences during their course of study is done greatly with help of ICT through posting information on students' portal, social media, email, and websites (the university, faculty and department). (A male non-science undergraduate respondent said)

Their results are posted on the students' portal which are person to holder for personal easy access at all times. (A female non-science undergraduate respondent said)

Photocopying of various documents while studying is greatly utilized. In the classrooms, there exists projectors, computers, posters, and maps among others which are of value to enhancing the teachinglearning process hence better comprehension. (A female science undergraduate respondent said)

Financial matters of learners are done online or in the bank and verified thoroughly well using ICT which has greatly minimized forgeries on the part of students and has enhanced transparency and accountability on part of the management as the case is in Kyambogo University. (A female non-science postgraduate respondent said)

From the above responses, ICT has increasingly made the management of KyU friendly to all parties hence more resultoriented performance and less time wasting. This is evident at Makerere University which had not fully embraced ICT in these aspects, the recent investigation committee instituted by the President of Uganda in its draft report of 2016 indicated various financial anomalies on the part of students and managers. For students it was for not paying at all or fractions or forgeries vis av those registered to study and sit examinations while for the managers it was short of transparency and accountability of all tuition fees payment and other incomes because of neglecting ICT either intentionally or otherwise.

In a nutshell, the role of ICT in enhancing higher education has become vital and attracting attention from various stakeholders. Originally it was viewed as a luxury and optional from many higher education scholars, mangers, students, professors and the country leaders. Today, given the accruing education benefits as evident above, ICT is now being viewed as a necessitate and a standard for measuring quality education /institutions.

\subsection{Challenges of ICT Application in Higher Education and Education Implications}

From the interviews, the respondents were asked the challenges of ICT application Higher Education (HE) and education implications. Their responses are categorized into four themes namely: Academic Staff, Learners, Economy, and Equipment. 
Table 5. Shows A Summary of The Challenges, Respondents and Responses of ICT Application and Education Implications in Higher Education

\begin{tabular}{l|l|l|l|l}
\hline S/N & Challenges & $\begin{array}{l}\text { Number of } \\
\text { Respondents }\end{array}$ & $\begin{array}{l}\text { Response } \\
\text { Status }\end{array}$ & Summary of Response \\
\hline 1. & Academic Staff & 87 & True & $\begin{array}{l}\text { Academic staff are a real challenge to } \\
\text { ICT application in HE }\end{array}$ \\
\hline 2. & Learners & 87 & True & $\begin{array}{l}\text { Learners are a real challenge to ICT } \\
\text { application in HE }\end{array}$ \\
\hline 3. & Economy & 87 & True & $\begin{array}{l}\text { Economy of Uganda is a real challenge } \\
\text { to ICT application in HE }\end{array}$ \\
\hline 4. & Equipment & 87 & True & $\begin{array}{l}\text { Equipment is a real challenge to ICT } \\
\text { application in HE }\end{array}$ \\
\hline
\end{tabular}

Source: Primary Data, 2020.

Table 5 above shows that all the respondents responded on the challenges of ICT application in Higher Education as true /real and below is the detailed response and interpretation.

\subsubsection{Academic Staff}

This dealt more with academic staff competences and attitudes towards ICT in this Information Age and below is the response from learners:

Limited qualified academic staff to teach ICT in universities. The demand for ICT learning has been tremendous and the number of academic staff who are trained to teach ICT cannot meet the demand. There are more students willing to be taught computing skills than there are academic staff able to teach ICT skills. (A male science undergraduate respondent said)

There is a continuous fear by some of the academic staff of becoming irrelevant by the introduction of ICT in their classes hence show a negative attitude which blocks the growth of ICT. (A male non-science postgraduate respondent said)

Some of the academic staff are not confident to use and apply ICT in their preparation and during the teaching-learning process which makes them oppose it, or neglect or do not apply. (A female science undergraduate respondent said)

A male non-science respondent testified that $50 \%$ of the academic staff do not have good offices equipped with ICT, personal laptops, modem, and smart phones which makes them oppose or neglect ICT implementation in $\mathrm{HE}$

From the above responses, there are large number of academic staff that do not have good offices equipped with ICT, connected to internet, personal laptops, modem for connectivity, cameras, television, and smart phones which makes them liability to ICT implementation in HE hence impacting negatively on the teaching-learning process. This was even noted earlier (Lubaale, 2015b \& Becta (2014).

\subsubsection{Learners}

This was more concerned with learner's application and use of ICT in this Information Age in the current circumstances of $\mathrm{KyU}$ and the nation at large and below is the response:

Learners who are not informed particularly those from poor social- economic background find difficulty in mixing with those who known a great deal besides feeling inferior and eventually unable to copy up and the reverse is true. (A male science undergraduate respondent said)

Learners with phobia, hatred, unfounded fear and prejudice over ICT find learning environment very difficult. (A female non-science postgraduate respondent said)

Learners with impairments like being unable to hear, see, walk, and touch, slow learners, and gifted students among others encounter great challenges of using ICT in a competitive manner with other students given the demands of the curriculum being the same. (A female non-science undergraduate respondent said)

The specialized ICT gargets that learners with special needs need to use for learning are very expensive and not always available hence creating difficult situations in teaching them. Many normally drop out 
or miss completely or perform poorly because of ICT deficiencies on their part. (A male science postgraduate respondent said)

From the above responses, it is clear that many learners still have ICT inadequacies in terms of competence, ability to purchase and own their personal laptops, modem for connectivity, cameras, television, and smart phones for ease of access to information which continue to keep their performance low in this era of computer age. This was even noted earlier (Lubaale,2015c).

\subsubsection{Economy}

This dealt with the economy of Uganda in terms of the National Budget and available resources in the country to support ICT implementation in HE and below is the response:

Irregular electricity supply in the country where universities are not exceptional besides many parts of the country are without electricity which creates perpetual difficulties in ICT use and application at all times. (A male science undergraduate student said).

Some students join the university without good ICT knowledge as well as access to and application of ICT in learning as result of ICT accessories shortages in the economy which eventually contributes to their poor academic and social performance. (A female science undergraduate student said).

Computers are still expensive in Uganda, in a country with a budget which is still donner dependent makes majority of the individuals and universities unable to afford computers and thus consider it as a luxury item. (A female non-science postgraduate student said).

Second hand computers cost as little as $\$ 250$ and branded new computers being sold at $\$ 1100$ or higher. Many university students and staff cannot easily afford. (A female science postgraduate student said).

Limited internet in some areas or band width or slow connectivity in many areas remains an obstacle to ICT use in Universities. Besides, most higher education learning institutions are not able to connect to the world wide web, due to the high costs involved in the connectivity. This is considered as very expensive that some cannot easily afford. (A male non-science undergraduate student said).

In view of the above responses, it is clear that the economy of Uganda is still struggling and given the fact that it is a developing nation, this practically means limited electricity, and shortage of ICT equipment in the economy through out because they are expensive. In the end, ICT remains a preserve for middle class in which many university students do not fall. When the students get to the university, they again find shortages of ICT accessories as noted above in $\mathrm{KyU}$ with 862 computers below the average target, less internet connectivity and no printing services among others. All these ICT shortages as a result of the economy and as even noted much earlier (Lubaale, 2015a) indeed become a stonewall of many students from accessing ICT hence low performance.

\subsubsection{Equipment}

This dealt with ICT equipment in the country in terms of imports, open market, access, quality, quantity and availability which blocks ICT use in the Universities as evident below by respondents:

Inadequate computers largely because computers are still very expensive and despite spirited efforts by the Ministry of Education and Sports and patterns like Chinese Funds In Trust, Non-Governmental Organizations (NGO), and Corporate organizations to donate computers to KyU, besides the University Council purchasing ICT equipment, the gap remains big and $\mathrm{Ky} U$ is unable to close it hence affecting students. (A female science undergraduate student said).

Obsolete computers lower the morale of both the academic staff and the student yet a fact that such very old computers running on window 2000 or window 2007 are still found in universities. (A male science postgraduate student said).

Continuous existence of broken computers in the university which have not been adequately equipped, under maintenance and repair, hence its very common to see a university computer laboratory full of broken-down computers. (A female non-science undergraduate student said).

There is a challenge of either importation or receive external ICT support in terms of computers and related accessories which have on a larger scale been of poor quality, and of second class that easily break down. (A male non-science postgraduate student said).

Theft of computers even though old and broken down hence becoming a source of insecurity wherever they are installed. This makes universities incur extra costs of burglary proofing, security guards and replacing stolen computers from time to time. (A male science undergraduate student said). 
From the above responses, it is clear that ICT equipment in the country is inadequate and of lower quality besides being expensive hence universities getting a low deal. Uganda is seen as a dumping ground and store of e-waste management from western countries which is harmful in all forms. At end of the day, students suffer greatly with inadequate ICT facilities in the universities as noted (Lubaale, 2012) hence leading to poor academic and social performance of learners as well as staff being unbale to make adequate and professional preparation for learners.

In a nutshell, from the above results and discussions, it is now clear that the teaching- learning process in HE institutions of Uganda is generally at large suffering from the digital divide as a result of limited financial resources and distributive capacity of ICT accessories. That is why Ugandan government has not been able to fully provide resources to keep up with this demand which has compromised the quality of HE in the country.

\section{Conclusion}

It is now clear that ICT has a central role in HE institutions in terms of enhancing the teaching-learning process, comprehension of learners, efficiency of the academic staff and professionalism as well as in the management of HE institutions. However, the digital divide among students, academic staff, and regions is wide and poses a threat for ICT enhancement in HE besides constrained financial resources in the economy of Uganda. This digital era has placed HE in a trick position of relevance with challenges of completely a new nature with both local and global perceptive which require concerted effort from all stake holders in order for ICT to thrive in HE so that it can enhance performance of leaners, academic staff and management.

\section{The Way Forward for ICT in Higher Education}

\subsection{National ICT Policy 2014}

Uganda has put in place a Ministry of ICT since 2011 to enforce and ensure that the National ICT policy 2014 which aims at improving the livelihoods of Ugandans by ensuring the availability of accessible, efficient, reliable and affordable ICT services as well as closing the digital gap is implemented holistically in which HE will benefit automatically. KyU should therefore be on the outlook of these opportunities from time to time so that the Institution can benefit very well.

\subsection{Growing Economy}

The economy of Uganda has consistently improved from $\$ 46$ billion in 1986 to $\$ 40.5$ trillion in 2019 (Uganda Budget Book, 2019). This will enable easy purchase of ICT equipment of quality and maintenance, reducing taxes on imports, and trade in these items will be easier and thus many quality items on market. Higher Education subsector will be able to purchase many ICT equipment and infrastructure needed to boost it hence better ICT implementation in the universities in Uganda including KyU.

\subsection{ICT Policies}

Higher Education Institutions must draw up their own ICT policies that address issues of the availability, accessibility, efficiency, reliability and affordability of ICT services for their staff, students and managers. This will certainly create efficiency and effectiveness among learners in doing assignment, submission and searching for data. The staff will be able to deliver lectures on time, be current with right information, and work closely and more friendly with learners in enhancing academic achievements. The managers and administrative staff will be able to deliver services like financial collections, accounting, auditing and budgeting easier. Every staff and students should go through ICT training and mentorship in order to deliver well with ICT equipment and be enforced by the University Senate.

\subsection{Close the Digital Gap in Education}

The Ministry of Education and Sports (MoES) must complete her drat ICT policy of 2014 of education by 2020 so that all learning institutions are compelled to follow it in addition to other policies of their own or best practices from other learning centers globally. The proposed changes in the lower secondary curriculum beginning in 2020 should make ICT compulsory at lower secondary and upper secondary as well which will go along way in closing the digit divide among schools, regions and learners because of having a uniform ICT curriculum for all in the country.

\subsection{Create Awareness}

Individual members (staff, students and parents) need to be sensitized by the Ministry of ICT, Ministry of Education \& Sports, and University Senate about the benefits of ICT in education so that they can sponsor themselves or their family members to own and access ICT gadgets like laptops with internet modem, computers and printers, and smart phones among others. These ICT gadgets will enable them to excel in academics and their usual work because of easy access to data, communication, delivery and accessibility.

\subsection{Standard Importation}

The government has now put strict measures on any person, NGO or corporate bodies willing to donate second hand 
computers for verification first and only those ICT accessories that pass the test and standard of Uganda that will be allowed in the country hence safely guarding Ugandans. HE will certainly benefit from this restriction. This will further compel donners to send better ICT facilities hence a great deal for HE. By effectively implementing this restriction, Uganda will automatically be saved from being a dumping ground and western countries e-waste store hence safety in Uganda.

\section{Acknowledgements}

Appreciation to Kyambogo University for the employment opportunity as a Senior Lecturer of Education, Professor Godfrey Ejuu for the manuscript editorial support, my respondents who freely \& willingly attended to me and my family members namely: Clare, Joanna, Abigail, Nathan, and Cranmer for the moral support.

\section{References}

Amin, E. (2005). Social Science Research: Conception, Methodology and Analysis. Makerere University, Kampala. https://www.worldcat.org/title/social-science-research-conception-methodology-and-analysis/oclc/157025594 (Accessed on $14^{\text {th }}$ of October 2019).

Anwar, S., \& Matthew, S. (2014). The contribution of ICT in higher education: A multifaceted Approach. IOSR Journal of Electronics and Communication Engineering, 9, 60-63. https://doi.org/10.9790/2834-09156063

Bates, T. (2010). The strategic management of e-learning in universities and colleges. Keynote presentation / World Conference on E-Learning in Corporate, Government, Healthcare, and Higher Education Volume 2010, Number 1Florida, R. (2002).

Bean, J. P. (2005). Light and shadow in research design. C. F. Conard \& R. C. Serlin (Eds), The sage handbook for research in education: engaging ideas and enriching inquiry. Sage Publications, California. Res. 353-372

Becta (2003). What research says about ICT and whole school improvement. UK: Becta. Accessed at: $\mathrm{http} / / /$ www.becta.org.uk/page_documents/research/wtrs_ws_improvement.pdf

Becta (2004) A review of the research literature on barriers to the uptake of ICT by Teachers' UK: Becta: Accessed at: http://www.becta.org.uk/page_documents/research/barriers.pdf

Creswell, J. W. (2009). Research Design: Qualitative, Quantitative, and Mixed Methods Approach. $3^{\text {rd }}$ Ed. USA: SAGE Publications

https://scholar.google.com/scholar?q=Research+Design:+Qualitative, + Quantitative, + and+Mixed+Methods+Appro ach. +3 rd + Ed. + USA: + SAGE + Publications + Inc\&hl $=$ en\&as $s d t=0 \&$ as vis $=1 \&$ oi $=$ scholart $\quad\left(\right.$ Accessed $\quad$ on $20^{\text {th }}$ January, 2020

Creswell, J. W., Vicki, L., \& Plano, C. (2017). Designing and Conducting Mixed Methods Research. Sage Publications $3^{\text {rd }}$ Edition. https://us.sagepub.com/en-us/nam/designing-and-conducting-mixed-methods-research/book241842 (Accessed on $10^{\text {th }}$ January, 2020).

Empirica (2006) 'Benchmarking Access and Use of ICT in European Schools', Empirica, 2006. http://ec.europa.eu/information_society/eeurope/i2010/docs/studies/final_report_3.pdf

Government of Uganda (2007). Comprehensive National Development Planning Framework (CNDPF). Kampala.

Government of Uganda (2011). Ministry of Information and Communication Technology (MoICT). Accessed from: Ict.go.ug/wp-content/uploads/2020/02/ICT-Sector-SIP.pdf

Government of Uganda (2013). Uganda Communications Act 2013, in Uganda gazette no.4 volume CVI dated $18^{\text {th }}$ January 2013

Government of Uganda (2013). Uganda Vision 2040. Enacted on $18^{\text {th }}$ April, 2013. Uganda Vision 2040. http://www.npa.go.ug/uganda-vision-2040

Government of Uganda (2018). Uganda Communications Commission 2018 Sector Performance, December 2018. Accessed on: Ucc.co.ug/wp-content/uploads/2017/09/ucc-Sector-Report december-2018_260719.pdf

Government of Uganda (2019). Budget Handbook Book 2019/2020. Kampala. https://www.mediacentre.go.ug/media/shs405-trillion-20192020-budget-presented-parliament

Kayiwa, S. J., Abu, R., \& Che, K. C. (2016). The Role of ICT in Higher Educational Administration in Uganda. World Journal of Educational Research, 3(1), 20163. https://doi.org/10.22158/wjer.v3n1p1

Kiptalam, K., \& Rodrigues, A. J. (2010). Accessibility and utilization of ICTS among secondary school teachers in Kenya retrieved from http://www.ictworks.org/2011/09/12/12-challenges-facing-computereducation-kenyan-schools 
Kyambogo University (2014). Kyambogo University Information and Communication Technology Policy, 2014. Kyambogo University, Kampala. Retrieved from: Kyu.ac.ug/wp-content/uploads/2019/01/Kyambogo UniversityICT-Policy-Framework_3.pdf

Kyambogo University (2019). Budget of Approved Estimates of Revenue and Expenditures (Recurrent and Development) of 2019/2020 Financial Year. Kyambogo University, Kampala

Kyambogo University (2019). ICT Directorate of Kyambogo University Records. Kyambogo University, Kampala

Kyambogo University (2019). Kyambogo University Graduation Booklet 2019. Kyambogo University, Kampala.

Lubaale, G. (2012). Tertiary Institutions: Theory, Practice and Opportunities: Cases of Makerere, Kyambogo and Uganda Martyrs Universities of Uganda in Delivering Quality Education for Development. Lap Lambert Academic Publishing GmbH \& Co.KG and Licensors; 2012: ISBN: 978-3-8484-0755-2, http://dnb.d-nb.de

Lubaale, G. (2015a). Benefits of ICT In Education: Teaching-Learning Process. African Journal of Education, Science and Technology. University of Eldoret (Kenya) and Anambra State University (Nigeria), 2(4), 2015 ISSN: 23099240 http://ajest.uoeld.ac.ke

Lubaale, G. (2015b). Challenges of Teacher Education in Enhancing Development: Cases of Makerere and Kyambogo Universities of Uganda. African Academic Research Forum, South Africa, 2015. ISBN 978-0-620-65950-5. www.aa-rf.org

Lubaale, G. (2015c). Improving Teacher-Learner Assessment Theory and Techniques in Higher Education: The Case of Makerere, Kyambogo And Uganda Universities of Uganda. African Academic Research Forum, South Africa, 2015. ISBN 978-0-620-65950-5. www.aa-rf.org

Mugenda, O. M., \& Mugenda, A. G. (1999). Research Methods. Quantitative and Quantitative Approaches. Nairobi: Centre for Technology Press. https://books.google.co.ug/books/about/Research_Methods.html?id=4WyrAAAACAAJ\&redir_esc=y (Accessed on $10^{\text {th }}$ January 2017).

National Council for Higher Education (2019). Universities in Uganda. Kampala. http://www.unche.or.ug/webpages/contacts.aspx. (Accessed on 12 ${ }^{\text {th }}$ December, 2019).

Nelly, C. A. (2015). Challenges of Adoption of Information Communication Technology on Teaching and Learning in Public Preschools in North Rift Region, Kenya. International Journal of Economics, Commerce and Management United Kingdom, III(12), 515. http://ijecm.co.uk/ISSN 23480386

Passey, D., \& Rogers, C. (2004). The Motivational Effect of ICT on Pupils'. UK: Lancaster University. Accessed at: http://www.dfes.gov.uk/research/data/uploadfiles/RR523new.pdf

Pope, C., Mays, N., \& Popay, J. (2007). Synthesizing qualitative and quantitively health evidence: A guide to methods. McGraw-Hill Education, New York. https://onlinelibrary.wiley.com/doi/full/10.1111/j.1467-9566.2007.1077_5.x (Accessed on $10^{\text {th }}$ January 2017).

Scrimshaw, P. (2004). Enabling teachers to make successful use of ICT'. UK: Becta. Accessed at: http://www.becta.org.uk/page_documents/research/enablers.pdf

United Nations (2005). UNESCO-2005 Information and communication technologies in schools: a handbook for teachers or how ICT Can Create New, Open Learning Environments. Paris, France.

\section{Copyrights}

Copyright for this article is retained by the author(s), with first publication rights granted to the journal.

This is an open-access article distributed under the terms and conditions of the Creative Commons Attribution license which permits unrestricted use, distribution, and reproduction in any medium, provided the original work is properly cited. 